\title{
PROJETO ARQUITETÔNICO ESTAÇÃO CHÃO D'ÁGUA E PROPOSTA DE TBC
}

\section{VICTOR GUILHERME CORDEIRO SALGADO | UNIFAP BIANCA MORO DE CARVALHO, Dra. | UNAM}

\section{AS PALAFITAS DA VILA ELESBÃO (AP)}

Apesar da Amazônia concentrar grande reserva de recursos naturais, sendo o maior conjunto de florestas tropicais do planeta, existem cenários de pobreza e exclusão em suas grandes cidades. Particular ao caso da cidade de Santana (AP), a inauguração da Área de Livre Comercio de Macapá e Santana (ALCMS) potencializou o contexto migratório de transferências de populações em busca de oportunidades no território.

As populações fixaram residência próximo a tal eixo industrial, isto é, na Zona Portuária de Santana, onde fica a Vila Elesbão em circunstância de assentamento popular, que somam mais de seis décadas de ocupação.

A origem cultural de muitas famílias migrantes influenciou no principal tipo de elemento edilício presente (palafita) uma vez confirmado que eram das ilhas próximas. Não se pode ignorar o fator socioeconômico, afinal foi necessário mão-de-obra barata para erguer o polo industrial portuária santanense.

A palafita ainda é a principal técnica construtiva desempenhada pela comunidade. São predominantemente erguidas pela autoconstrução, com fortes traços das palafitas vernáculas, contudo já subsidiadas com materiais e equipamentos contemporâneos, ou seja, são encontradas estéticas hibridas, em adaptação, diante das possibilidades econômicas das famílias.

A vista da janela ou da varanda contempla a imensidão de água doce, vegetação exuberante de ilhas próximas e embarcações de grande porte, sem falar das embarcações tradicionalmente produzidas pelos carpinteiros navais locais.

\section{O PROJETO E PROPOSTA DE DESENVOLVI- MENTO LOCAL}

O conjunto de razões que contemplam o planejamento arquitetônico deste projeto e proposta de desenvolvimento local reúne dez termos que fundamentam a temática principal: cultural local; meio ambiente; justiça social, coletividade, uso público; materiais locais; inovação; acessibilidade; autogestão comunitária; e apropriação. Inspirado nos objetivos da Agenda 2030 para o Desenvolvimento Sustentável (UN, 2014).
A forma final da edificação apresenta implantação com especificidades para cada bloco. Seguindo o traçado alongado do fragmento norte da poligonal, o Bloco $B$ "Convés", e comprimindo-se a sul, o Bloco A "Margem. As denominações Margem é inspirada na fronteira água-terra e Convés na forma interior de embarcações grandes.

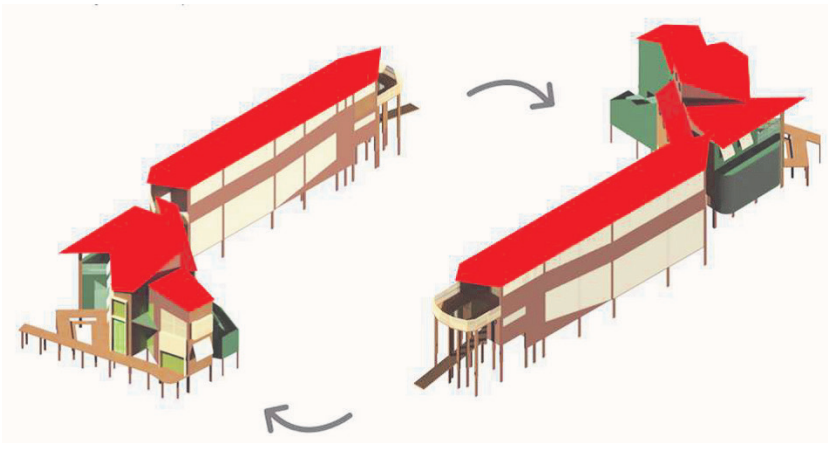

Figura 1 - Edificação palafitica. Fonte: Autores, 2019

O Bloco "Margem", apresenta-se a forma agrupada, de linhas retas e cruzamentos diversos, inspirada nos sentidos oblíquos que as passarelas e aglomeração de assentamentos populares geralmente adquirem. A disposição horizontal do Bloco "Convés" tem formato longitudinal alongado, com proa, varanda e quintal. Este bloco é destinado aos usos mais versáteis e livres, com espaços concebidos para atender as transformações e improvisos pertinentes ao modo de vida de populações socialmente mais frágeis.

O Turismo de Base Comunitária (TBC) objetiva a vivência intercultural, a qualidade de vida, a valorização da história e cultura das comunidades gestoras, bem como a utilização sustentável para fins recreativos e educativos dos recursos presentes na localidade (ICMBIO, 2017).

O modelo de gestão foi apresentado a comunidade da vila, representada pela associação de moradores, por meio do site de simulação experimental criado para visualização dos serviços e competências possíveis a realidade local. Ideia foi orientada de acordo com outras duas 
experiências de TBC na Amazônia e compreende a preexistência de metodologias para cada etapa de consolidação do empreendimento.

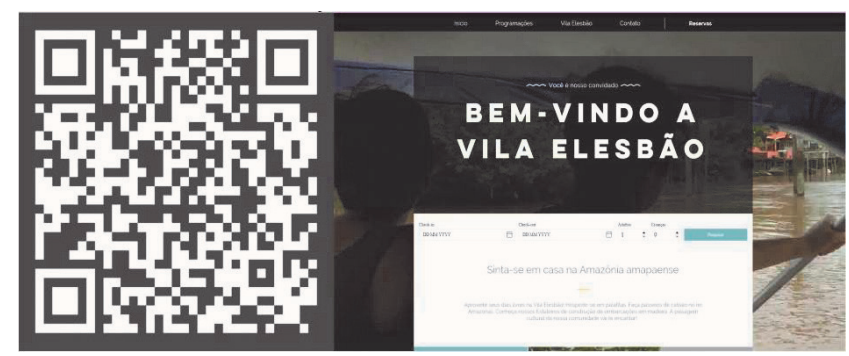

Figura 2 - Site Elesbão Turismo.

Fonte: Autores, 2019.

\section{REFERÊNCIAS}

ICMBIO, Instituto Chico Mendes de Conservação da Biodiversidade. Turismo de Base Comunitária em Unidades de Conservação Federais. Princípios e Diretrizes. Coord.: Thiago Souza et. al. Ministério do Meio Ambiente. Brasília. 2017.

UN, United Nations. The road to dignity by 2030: ending poverty,transforming all lives and protecting the planet. Synthesis report of the Secretary-General on the post-2015 sustainable development agenda,

NewYork, 2014. 